\title{
Veinte años de Espiral
}

DOI: https://doi.org/10.32870/eees.v21i60.296

Con este número celebramos veinte años de existencia de nuestra revista y la continuidad del proyecto Espiral. Dos décadas de mirar críticamente la realidad social, desde distintos ángulos, con perspectivas metodológicas y teóricas diversas y respetando el carácter interminable, inacabado, del mundo social. De ahí que el emblema de nuestra publicación sea justamente esta figura geométrica. Por ello, aunque cada una de nuestras portadas sea única, en todas ellas aparecen imágenes, pinturas, fotografías, murales que representan una voluta.

Nos hemos propuesto contribuir a la renovación de los conceptos con que analizamos los fenómenos sociales. Hemos recogido aportaciones de la comunidad científica de las ciencias sociales de México, América Latina y el resto del mundo. También hemos colaborado en la difusión nacional e internacional de la producción científica de la División de Estudios de Estado y Sociedad del Centro Universitario de Ciencias Sociales y Humanidades de la Universidad de Guadalajara.

La revista ha tenido como línea editorial el mantenimiento de una actitud universalista, tolerante y plural. Nos hemos empeñado en la construcción de una revista de gran calidad académica, capaz de abrir sus páginas a los conocimientos más avanzados y rigurosos posibles y de funcionar con criterios de estricto arbitraje académico, siguiendo normas de arbitraje interno y externo y el sistema de arbitraje doble-ciego, etc.; además, recurriendo a una extensa cartera de árbitros de reconocido prestigio en la comunidad académica de México, América Latina, España, 
Estados Unidos y Francia, entre otros lugares. Adicionalmente, nuestra revista se ha integrado a importantes índices internacionales, entre los que destacan el Índice de Revistas Mexicanas de Investigación del CONACYT, el Sociological Abstracts, el Hispanic American Periodicals Index de la UCLA, el Índice CLASE de la UNAM y el de la Red Latinoamericana de Revistas de Ciencias Sociales y Humanidades de ALAS. Espiral, además, puede ser consultada en línea en la Red de Revistas Científicas de América Latina y el Caribe (Redalyc).

Hemos tenido la suerte de contar con un comité editorial integrado por investigadores que gozan de un gran reconocimiento en sus campos de estudio, tanto a escala nacional como a escala internacional. Algunos de ellos(as) profesores adscritos a la Universidad de Guadalajara y al Sistema Nacional de Investigadores; otros(as), a instituciones de la región, como el ITESO o El Colegio de Jalisco, o bien adscritos a instituciones nacionales, como El Colegio de México, el Instituto de Investigaciones Sociales de la UNAM o el CIESAS; el resto, procedentes de instituciones internacionales, como el Centro para el Estudio de las Américas (EEUU), la Universidad Federal de Goiás (Brasil), la Trobe University (Australia), la Universidad de Chile, la Universidad de Texas en Austin (EEUU), la Universidad de París XIII (Francia), la Universidad Complutense de Madrid (España) y el European University Institute (Italia).

Por nuestras páginas, además de los autores de nuestra Institución, han pasado investigadores tan connotados como Claus Offe, Guillermo de la Peña, Susan Street, Pierre Salama, Zygmunt Bauman, Ángel Bassols, Alonso Lujambio, Juan Manuel Ramírez Saíz, Pablo Latapí, Janaina Amado, Fernado Mires, Fernando Cortés, Alberto Aziz, Mary Louise Pratt, Bruno Lautiere, Pablo González Casanova, Marguerite Bey, Blandine Destremau, David 
Medio centenar de números de la revista Espiral

Barkin, Jean Francois Lessard y Mario Lanzzaroti, entre muchos otros.

En los últimos años se han discutido en nuestra sección Teoría y debate temas como el medio ambiente, la subjetividad, el psicoanálisis, el capital social, la teoría poscolonial, la disociación entre teoría y datos empíricos, las prácticas sociales, la acción colectiva, los regímenes de bienestar, el concepto revolución y el futuro de la democracia en México. Muchas temáticas relacionadas con el Estado se han abordado en la sección que lleva ese nombre, tales como las políticas de vivienda, las políticas sociales, las políticas industriales, los derechos humanos, la construcción de instituciones democráticas, los sistemas de salud, las políticas de investigación, la inseguridad y la violencia, el acceso a la información, etc.

De igual forma, se ha acometido el análisis de una gran cantidad de problemas relacionados con la sociedad, entre ellos las contradicciones de la democracia liberal, la pobreza y el empobrecimiento, la desigualdad, la vulnerabilidad social, la inequidad urbana y metropolitana, la autonomía indígena, la resistencia político-sindical, la migración, las organizaciones sociales, los estudios sobre la juventud, la pobreza y el género, la blogosfera, el trabajo y la ciudadanía social, la reforma social, la economía regional, así como un largo etcétera.

Durante estos 20 años se han publicado 391 artículos científicos, aproximadamente 145 reseñas de libros y multitud de reseñas críticas. Nuestros autores y autoras han recurrido a perspectivas históricas, estructurales, constructivistas, al análisis discursivo y a teorías que privilegian a los actores sociales. Aunque hemos prestado una especial atención a la realidad mexicana, a sus regiones, y de manera particular a Jalisco, se han publicado estudios comparativos y estudios de caso de países europeos, asiáticos, de América del Norte y de Latinoamérica. 
Los trabajos que han aparecido en nuestras páginas han utilizado abordajes disciplinarios, interdisiplinarios y trasdiciplinarios, enfoques cualitativos y cuantitativos, escalas globales y locales, perspectivas macro y micro. Se han presentado complejos estados de la cuestión alrededor de corpora amplios de estudios sobre problemas concretos, etc. No solo nos hemos conformado con presentar análisis cuidadosos, sino que hemos difundido visiones que proponen cambios deseables.

Después de dos décadas, consideramos que tenemos una identidad académica muy clara y que hemos ganado un lugar muy sólido en el conjunto de las publicaciones períodicas de ciencias sociales de nuestro país. Por ello, nos sentimos muy orgullosos. Todo esto ha sido producto del notable esfuerzo de la División de Estudios de Estado y Sociedad del CUCSH, de la UdeG, el cual ha sido animado por un denuedo colectivo y un impulso interinstitucional en el que han participado numerosas redes académicas de México, América Latina y muchos otros países. Nuestra intención es continuar con nuestra rigurosa empresa plural y abierta a México y el mundo. Muchas gracias.

Consejo directivo

Jorge Alonso

Carlos Barba

Jaime Preciado

Jaime Tamayo 